\title{
Severity of winter seasons in the northern Baltic Sea between 1529 and 1990: reconstruction and analysis
}

\author{
S. Jevrejeva ${ }^{1,2, *}$ \\ ${ }^{1}$ Estonian Meteorological and Hydrological Institute, Rävala pst. 8, Tallinn 10143, Estonia \\ ${ }^{2}$ Tallinn Pedagogical University, Narva mnt. 25, Tallinn 10120, Estonia
}

\begin{abstract}
This paper presents the reconstructed severity of winter seasons in the northern Baltic Sea on the basis of historical time series of ice break-up at the port of Riga (1529-1990). The winter seasons are classified as mild, average severe. Results of statistical analysis of time series of the date of ice break-up arranged according to the severity of winter seasons are given. A decreasing trend of about $2.0 \mathrm{~d} \mathrm{century}^{-1}$ for the time series of ice break-up dates for severe winters is detected with statistical significance at the $99.9 \%$ level; for the mild and average winter seasons the trends are statistically insignificant.
\end{abstract}

KEY WORDS: Ice conditions $\cdot$ Severity of winter seasons $\cdot$ Baltic Sea $\cdot$ Trend

\section{INTRODUCTION}

Ice conditions are sensitive indicators of climate change. There have been several studies concerning climate reconstruction based on proxies from ice parameters. Camuffo (1987) investigated freezing in the Venetian Lagoon; the dates of freezing and break-up of rivers in Canada were used by Rannie (1983); and Catchpole \& Hanuta (1989) analyzed ice cover in Hudson Bay.

In the Baltic Sea area, extreme ice conditions have been documented in the historical chronicles since AD 690 (Speerschneider 1915, Lamb 1977). However, these were limited to remarks of unusual ice conditions occurring in the southern Baltic. Periodic recordings of ice observations started in the 16th century, when the harbor pilot service was initiated in Sweden. By decision of the government, the population along the coastal areas was obliged to establish navigation marks (Rudovic 1930). These navigation marks had to be established after the ice disappeared, and at the beginning of the ice season it was necessary to collect

*E-mail: sveta.jevrejeva@neti.ee the marks. This encouraged the beginning of sea ice observations. Another reason for ice monitoring was to allow the use of ice cover for laying down transportation routes during the winter season. We find detailed descriptions of these activities from, e.g., the Olaus Magnus Gothus chart 'Carta Marina' (16th century). On that chart there were drawn special ice roads in the eastern part of the Gulf of Finland, for travel from the northern to the southern shore. In the eastern parts of the Gulf of Finland covered by ice, sketches of battles have been preserved containing information on army transportation.

However, these were not regular observations, but rather occasional information about ice conditions. Regular observations in Sweden started in 1870. The first regular observations in Russia were started in 1706 at St. Petersburg. Subsequent observations were recorded at Narva (1837), Kronstadt (1814) and Buborg (1861) (Rukachev 1886). These early observations have contributed greatly to our knowledge of climate variations in the Baltic Sea region.

Jurva (1944) constructed a time series of maximum annual ice extent in the Baltic Sea dating back to 1720 , and this work was continued by Seinä \& Palosuo 
(1996). Spectral analysis of time series of the maximum annual ice extent in the Baltic Sea was carried out by Girljatowicz \& Kozuchowski (1995). Oscillations with 7 to $8 \mathrm{yr}$ periods were found in the ice cover series (1719-1992), but these become significant in the spectrum only in the most recent period (1900-1992). Oscillations with 3.5 and 5.3 yr periods were found for the years 1719-1800 and 1890-1900, respectively.

Tarand (1993) constructed time series of ice breakup in the port of Tallinn since 1501. Ice conditions in the western Baltic Sea have been analyzed in terms of a mass-related severity index by Koslowski \& Loewe (1996) and Koslowski \& Glaser (1995, 1999). Reconstruction of 7 types of winter severity was based on the accumulated areal ice volume along the German Baltic during 1501-1995. Variations in ice winter severity in the western Baltic were investigated; periods with increased and reduced severity were defined. The relation between different types of ice winter severity in the western Baltic and the North Atlantic oscillation (NAO) was examined.

Studies of changes in ice conditions along the Polish coast found a decreasing trend of about 1 to $3 \mathrm{~d}$ decade $^{-1}$ between 1896 and 1993 in a long-term time series of ice-covered periods along the Polish coast in the southern Baltic Sea (Sztobryn 1994).

In the present study the severity of winter seasons in the north Baltic Sea is reconstructed on the basis of historical time series of ice break-up at the port of Riga for the period 1529-1990.

\section{SCOPE OF THE STUDY}

The aim of this study is to define the severity of winter seasons in the northern Baltic Sea during 1529-1990 using historical records of ice break-up dates.

The objectives of the study were as follows: (1) to analyze the temporal variability in time series of ice break-up at the port of Riga; (2) to define the severity of winter seasons; and (3) to compare the reconstructed severity with available historical information

There are several definitions of ice winter severity types in the Baltic Sea area. Prüfer (1942) defined 4 ice winter types (mild, moderate, strong and very strong) using the number of days with ice and ice conditions for navigation. Girjatowicz (1990) classified 3 ice winter types (mild, moderate and severe) with respect to the sum of mean daily air temperature below $0^{\circ} \mathrm{C}$ from December through March, maximum ice thickness during the ice season and number of days with ice. Seven ice winter severity types defined by the ice concentration, ice thickness and index of days with ice were offered by Koslowski \& Glaser (1995). Betin
(1957) analyzed 3 ice severity types (mild, average and strong) in the Baltic Sea between 1903 and 1946 using the number of days with ice adjusted with regard to the limits to navigation. Seinä \& Palosuo (1996) classified 5 ice winter severity types based on maximum annual extent of ice cover in the Baltic Sea. The winters were classified as extremely mild (5200 to $81000 \mathrm{~km}^{2}$ ), mild (81001 to $139000 \mathrm{~km}^{2}$ ), average (139001 to $\left.279000 \mathrm{~km}^{2}\right)$, severe (279001 to $383000 \mathrm{~km}^{2}$ ) and extremely severe (383001 to $420000 \mathrm{~km}^{2}$ ). The correlation coefficient between the maximum annual extent of ice cover in the Baltic Sea and the mean air temperature from December to March at Mariehamn (Aland Island) during 1873-1992 is 0.91 (Seinä \& Palosuo 1996).

Jevrejeva (1999, 2000) classified 3 ice winter severity types for the coastal area in the Baltic Sea along the Estonian coast. The classification was based on data sets from 5 stations situated in the Gulf of Riga and 3 stations situated in the Gulf of Finland for the period 1890-1990; selected stations were located on the mainland and on the islands as well. Time series of daily air temperature from the ice condition observation places were used to calculate the sum of negative degree-days for each of the stations from the date of onset of freezing air temperatures to the date of onset of melting air temperatures. On the basis of obtained results the seasons used were classified as mild if the sum of negative degree-days was less than 380; as average if the sum was between 380 and 570; and as severe if the sum was more than 570 for the Gulf of Riga. Analogous classification was applied to the stations situated in the Gulf of Finland for the period 1890-1990.

In a previous study (Jevrejeva \& Leppäranta in press) ice conditions in the Baltic Sea along the Estonian coast from 1890-1990 were analyzed in detail. Long-term time series of date of freezing, date of fast ice formation, date of disappearance of fast ice, date of ice break-up and ice thickness for 8 stations situated along the Estonian coast in the Gulf of Finland and the Gulf of Riga were examined. Statistics (average, standard deviation, maximum and minimum) and frequency histograms were given; for trend analysis, the results of regression fit, correlation coefficients and significance level were presented. Time series divided according to the severity of winter seasons were also analyzed. For all observation stations mild winter seasons were characterized by an early date of ice breakup; a few weeks later the date of ice break-up was fixed for average winters and the latest date of breakup for the severe winters was found.

Additionally, the relation between time series of winter severity represented by the sum of negative degree-days and the date of ice break-up in the Gulf 
of Finland and Gulf of Riga was examined. The correlation coefficients between a 100-yr-long time series of dates of ice break-up and time series of the sum of negative degree-days for 8 stations situated along the Estonian coast were between 0.7 and 0.9 . This allows data on ice break-up date, which extends back in time much further than air temperature measurements, to be used as a proxy for ice severity of winter seasons.

The weakness of the classification based on the calculated sum of negative degree-days is that air temperature has been measured regularly along the Estonian coast only since 1890. Seinä \& Palosuo (1996) classified the winter seasons in the Baltic Sea since 1720. The 2 classifications were compared for the period 1890 to 1990 . The classification by Seinä \& Palosuo was simplified (the same simplification for a practical level was also mentioned by them)-extremely mild and extremely severe winters were considered as mild and severe, respectively - and thus only 3 types remained: mild, average and severe. There is remarkable agreement $(92 \%)$ between the classification of winter seasons used here based on the calculated sum of negative degree-days and Seinä \& Palosuo's classification based on maximum annual ice extent for the period of air temperature measurements (1890-1990). Some disagreements were detected for the winter seasons; for example, season 1949-50 with a sum of negative degree-days of 520 was classified as average by Jevrejeva $(1999,2000)$ and with $113000 \mathrm{~km}^{2}$ of maximum ice extent was classified as mild by Seinä \& Palosuo. Most of the disagreements relate to the mild winter seasons, when maximum ice extent can be redistributed by dynamic factors (strong wind, sea-level fluctuations, currents). In general, the correlation coefficients between the sum of negative degree-days for 5 stations situated along the Estonian coast in the Gulf of Riga and maximum annual ice extent in the Baltic Sea ranged from 0.85 to 0.91 . Assuming there is a strong relation between date of ice break-up and severity of winter seasons, we can use Seinä \& Palosuo's classification of winter severity between 1720 and 1890 as a proxy for negative degree-days.

\section{RECONSTRUCTION OF SEVERITY OF WINTER SEASONS FOR THE PERIOD 1529-1990}

\subsection{Historical time series of ice break-up at the port of Riga, 1529-1990}

The coastal areas in the northern and central Baltic Sea are covered by ice every winter. Ice conditions are recorded in many historical chronicles, as an important factor in the regulation of navigation. Riga is one of the
Hanseatic cities, with a long history of trade and archives containing port journals, custom books, town council minutes and trade company records.

Stakle (1936) published the first time series of ice break-up at the port of Riga, which was then extended by Betin (1957). The data for the period 1957-1990 have been collected from yearbooks in the library of the Estonian Meteorological and Hydrological Institute. In the present study, the date of ice break-up is considered as the date of disintegration of the ice cover in the period with regular ice observations. Before this period only information on the date of the beginning of navigation in the port of Riga is obtainable, which is assumed to be almost the same as the ice break-up date. There are some gaps for the period before 1708 , after which the data are continuous. The data since 1722 are in good agreement with air temperature measurements in the Baltic Sea (Uppsala, Stockholm and St. Petersburg time series) for the period before instrumental measurements, assuming that the extremes (the earliest and latest dates of ice break-up) were fixed more often and that gaps are related to the average date of ice break-up. There were no replacements of the data; original data were used in this study. For a regression run the gaps were deleted.

The time series of date of ice break-up (Fig. 1) is characterized by a mean date of 4 April (SD : $\pm 17 \mathrm{~d}$, median: 6 April). A decreasing linear trend (not shown here), significant at the $99.9 \%$ level, indicates that the date of ice break-up shifted earlier, about $1.5 \mathrm{~d}$ century $^{-1}$ (Table 1).

Outliers were screened through the residual analysis after an initial regression run in order to obtain results based on original data and to compare the results from the time series from which outliers were removed.

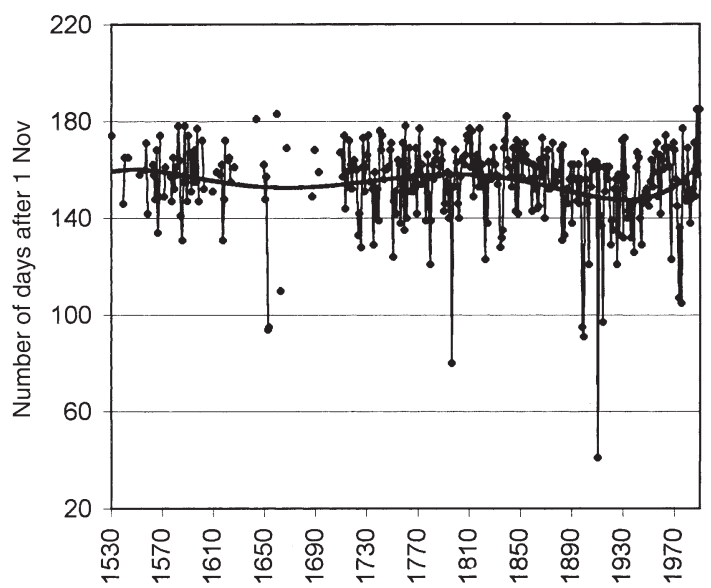

Fig. 1. Time series of date of ice break-up at the port of Riga. The fifth-order polynomial fitting curve indicates the periods of later and earlier break-up 
Table 1. Results of regression analysis for the linear trends of time series of break-up at the port of Riga for different winter-season severities

\begin{tabular}{|c|c|c|c|c|c|}
\hline & $\begin{array}{c}\text { All types } \\
(1529-1990)\end{array}$ & $\begin{array}{c}\text { Severe } \\
(1529-1990)\end{array}$ & $\begin{array}{c}\text { Average } \\
(1529-1990)\end{array}$ & $\begin{array}{c}\text { Mild } \\
(1529-1990)\end{array}$ & $\begin{array}{c}\text { Mild } \\
(1720-1990)\end{array}$ \\
\hline Standard error & 2.15 & 2.22 & 1.90 & 1.47 & 4.64 \\
\hline Number of observations & 346 & 117 & 118 & 111 & 88 \\
\hline \multicolumn{6}{|l|}{ Sums of square errors } \\
\hline Regression & 26.82 & 34.25 & 8.30 & 1.37 & 118.27 \\
\hline Residual & 1597.42 & 568.13 & 420.70 & 237.00 & 1856.34 \\
\hline Total & 1624.24 & 602.40 & 429.00 & 238.37 & 1974.61 \\
\hline \multicolumn{6}{|l|}{ Mean square error } \\
\hline Regression & 26.82 & 34.25 & 8.30 & 1.38 & 118.27 \\
\hline Residual & 4.64 & 4.94 & 3.63 & 2.17 & 21.59 \\
\hline$F$ & 5.78 & 6.93 & 2.29 & 0.63 & 5.48 \\
\hline Significance of $F$ & 0.016 & 0.009 & 0.13 & 0.43 & 0.02 \\
\hline Slope & -0.016 & -0.020 & -0.014 & -0.011 & -0.050 \\
\hline Intercept & 152.06 & 169.65 & 159.19 & 146.77 & 152.03 \\
\hline Student's $t$ of slope & 2.40 & 2.63 & 1.52 & 0.80 & 2.34 \\
\hline $\mathrm{p}$-value of slope & 0.016 & 0.009 & 0.13 & 0.43 & 0.02 \\
\hline \multicolumn{6}{|l|}{ Degrees of freedom } \\
\hline Residual & 344 & 115 & 116 & 109 & 86 \\
\hline Total & 345 & 116 & 117 & 110 & 87 \\
\hline
\end{tabular}

Once outliers were identified, the extreme cases were discovered. Eight extremely early dates of ice breakup were detected for the period 1529-1990; 4 were observed after 1850 (1897-98, 1898-99, 1909-10, 1913-14) and were confirmed by mild conditions in the Baltic Sea and available air temperature measurements. The historical information about extremely early break-up before 1850 is assumed to be qualitative, as in chronicles extremely mild winter seasons were described for those years. Eight outliers were detected and removed from the time series. After that the regression analysis was performed again. Standardized residuals were from -2.7 to 2.5 . The residuals were nearly normally distributed (skewness $=-0.2$; kurtosis $=0.6$ ); the points fell along a straight line. Leverage (Mahalanobis distance) was calculated for each point; critical $\chi^{2}$ at $\alpha=0.001$ for 2 df is 13.816 . None of the cases has a value in excess of 13.816 (maximum was 6.21). Influence was evaluated by calculation of Cook's distance (maximum was 0.049). The Durbin-Watson test result was in 1.893. Residuals did not show autocorrelated properties.

Even with outliers removed from time series, the decreasing linear trend is still statistically significant; there were no changes in slope.

Moving averages ( 7 or 12 yr periods) randomly fluctuate along the linear trend in the pre-1800 interval, possibly indicating red noise with no well-defined spectral lines. At the same time it is evident that some periods were dominated by early (1890-1945, 1970-1980) and late (1800-1890, 1945-1970) breakup relative to the trend line. It is important to empha- size that the duration and amplitude of periods with a tendency toward early and late dates of break-up are not equal. One simple way to look at low-frequency behavior is to fit a fifth-order polynomial curve to the data (Fig. 1).

The fifth-order polynomial fitting curve indicates the follow periods: (1) 1530-1640: period with a tendency toward early break-up; 9 d century $^{-1}$; (2) 1640-1770: period with a tendency toward late break-up; 5 d century $^{-1}$; (3) 1770-1920: period with a tendency toward early break-up; 15 d century $^{-1}$; and (4) 1920-1990: period with a tendency toward late break-up; $12 \mathrm{~d}$ century $^{-1}$.

The last period (1920-1990) is characterized by a tendency toward a late date of ice break-up, even though the 2 intervals 1945-1970 and 1980-1990 are characterized by early date of ice break-up (with respect to a decreasing linear trend line).

\subsection{Severity of winter seasons between 1720 and 1990}

As mentioned in Section 2, the winter seasons for the period 1720-1990 were classified as mild, average and severe. Time series of date of break-up at the port of Riga were constructed for the different types of winter seasons. Results of statistical analysis for the time series of ice break-up as a function of the severity of winter seasons are given in Table 2.

Histograms of date of ice break-up for the different type of winter seasons are plotted in Fig. 2. 
Table 2. Statistics of time series of ice break-up for mild, average and severe winters at the port of Riga during the period 1720-1990

\begin{tabular}{|lrrr|}
\hline & $\begin{array}{c}\text { Mild winter } \\
\text { seasons }\end{array}$ & $\begin{array}{c}\text { Average winter } \\
\text { seasons }\end{array}$ & $\begin{array}{c}\text { Severe winter } \\
\text { seasons }\end{array}$ \\
\hline Mean & $24 \mathrm{Mar}$ & $3 \mathrm{Apr}$ & $12 \mathrm{Apr}$ \\
SD & 20 & 15 & 10 \\
SE & 2.1 & 1.6 & 0.9 \\
Median & $26 \mathrm{Mar}$ & $6 \mathrm{Apr}$ & $12 \mathrm{Apr}$ \\
Skewness & -1.9 & -2.1 & 0.3 \\
Latest & $4 \mathrm{May}$ & $26 \mathrm{Apr}$ & $21 \mathrm{May}$ \\
Earliest & $11 \mathrm{Dec}$ & 19 Jan & $15 \mathrm{Mar}$ \\
Count & 88 & 88 & 94 \\
& & & \\
\hline
\end{tabular}

The shape of the histograms varies for different types of winter season. Mild winters show a flat distribution and are negatively skewed to the beginning of spring; severe winters are positively skewed to the end of spring, with a sharp peak. The date of break-up for severe winter is also characterized by the smallest standard deviation.

There were 88 mild (33\%), 88 average (33\%) and 94 severe $(34 \%)$ winters during 1720-1990. The time series were arranged according to the severity and trend analyses performed. In general, no linear trends were found for the severe and average winter seasons and a slightly decreasing trend ( $5 \mathrm{~d}^{\text {century }}{ }^{-1}$ ) was detected in time series of mild winter seasons, with statistical significance at the $98 \%$ level (Table 1).

\subsection{Severity of winter seasons between 1529 and 1720}

The statistical characteristics of time series of ice break-up for the period 1720-1990 have been used to establish a rank for each winter season for the period 1529-1720. According to the date of break-up, the winter seasons were defined as mild, average and severe. In addition, historical records from chronicles were used. The results are given in Table 3 .

As before, trends were analyzed for the different classes of winter severity. Decreasing trends of $1.5 \mathrm{~d}$ century $^{-1}$ for the average winter seasons and only $1 \mathrm{~d}$ century $^{-1}$ for mild winter seasons were found (Fig. 3), but statistical significance was below the $95 \%$ level. A decreasing trend of about $2 \mathrm{~d}$ century $^{-1}$ for the time series of date of ice break-up for severe winters was detected (statistical significance at the 99.9\% level, Table 1, Fig. 4). Residuals statistics are as follows: maximum Mahalanobis distance: 5.398, maximum Cook's distance: 0.122 ; result of Durbin-Watson test: 2.041 .

For more information about the consequences of ice break-up on the different classes of winter seasons, histograms were plotted.
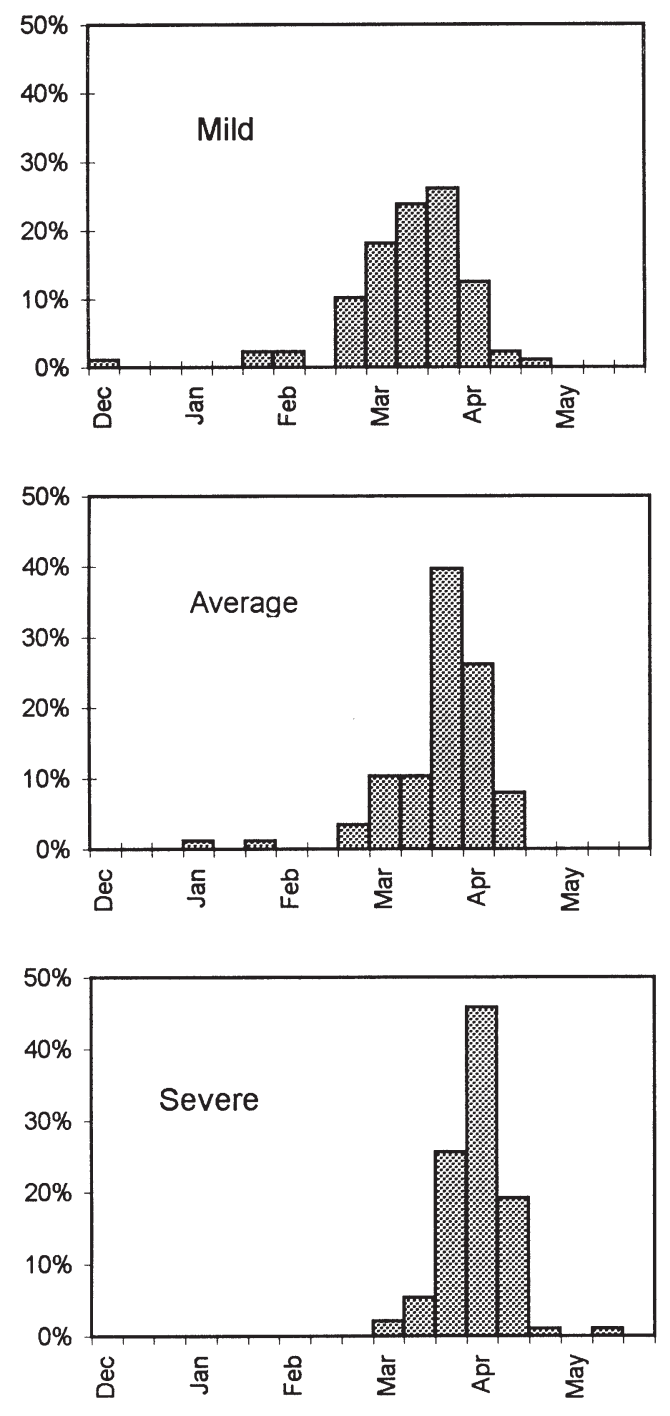

Fig. 2. Date (number of days from 1 November) of ice breakup for mild, average and severe winters (1720-1990)

\section{COMPARISON WITH OTHER RELEVANT DATA}

Every reconstructed winter season's severity index was carefully matched with available data from different sources (such as various chronicles). First, historical descriptions were used (Betin 1957). For example, the winter season 1579-80 was defined as strong with respect to the severe ice conditions described by Hennig (1904) and from a description about the trip from Tallinn over the Baltic Sea from Russian chronicles mentioned by Buchinsky (1957). The severity of the 1556-57 winter season is confirmed by a description of extremely severe conditions in northwestern Russia from Russian chronicles. The winter season 1620-21 was defined as severe based on the date of break-up at the Riga port and according to the information about 
Table 3. Reconstructed severity of winter seasons, 1529-1720

\begin{tabular}{|c|c|c|}
\hline Mild & Average & Severe \\
\hline 1538-39 & $1539-40$ & $1529-30$ \\
\hline $1557-58$ & $1542-43$ & $1551-52$ \\
\hline $1563-64$ & 1555-56 & $1556-57$ \\
\hline $1565-66$ & 1561-62 & 1564-65 \\
\hline $1566-67$ & 1562-63 & $1567-68$ \\
\hline $1570-71$ & $1575-76$ & $1571-72$ \\
\hline $1576-77$ & 1578-79 & $1577-78$ \\
\hline $1583-84$ & 1580-81 & $1579-80$ \\
\hline $1587-88$ & 1584-85 & $1581-82$ \\
\hline $1588-89$ & $1585-86$ & $1582-83$ \\
\hline $1593-94$ & 1590-91 & $1586-87$ \\
\hline $1597-98$ & 1591-92 & $1589-90$ \\
\hline $1608-9$ & 1592-93 & 1594-95 \\
\hline $1616-17$ & 1595-96 & 1596-97 \\
\hline $1617-18$ & 1601-2 & 1600-1 \\
\hline $1625-26$ & 1611-12 & 1618-19 \\
\hline $1649-50$ & 1614-15 & $1620-21$ \\
\hline $1651-52$ & $1615-16$ & $1642-43$ \\
\hline $1652-53$ & $1621-22$ & 1658-59 \\
\hline $1661-62$ & $1622-23$ & 1688-89 \\
\hline $1686-87$ & $1648-49$ & 1708-09 \\
\hline \multirow[t]{10}{*}{$1712-13$} & $1650-51$ & $1709-10$ \\
\hline & $1666-67$ & $1715-16$ \\
\hline & $1691-92$ & \\
\hline & $1710-11$ & \\
\hline & $1711-12$ & \\
\hline & $1713-14$ & \\
\hline & $1714-15$ & \\
\hline & $1716-17$ & \\
\hline & $1717-18$ & \\
\hline & $1718-19$ & \\
\hline
\end{tabular}

ice cover around Gotland until 1 May (Strelow 1633). The same ice conditions on the Baltic Sea along the Danish coast is confirmed by Speerschneider (1915). The severe winter of $1708-9$ is confirmed by Suhm (1793), who described the winter as severe until 3 April in Denmark. The Baltic Sea was covered by ice and sledges were used for transportation even in May 1709 (Thaarup 1776). Hard winter conditions in Ukraine are described by Shvetc (1955) and Kraft (1887).

An agreement was found for the periods of early and late ice break-up at the port of Riga and historical evidence from European countries (Glaser \& Hagedorn 1991, Pfister 1992, Rácz 1994).

Koslowski \& Glaser (1999) mentioned the cooling period from about 1650-1715 in western and central Europe, confirmed by the Maunder minimum of sunspot numbers (1645-1715). During that period the ice break-up observed at the port of Riga is characterized by the tendency toward late break-up dates, and consequently that period has been also characterized by severe and average reconstructed winter seasons.

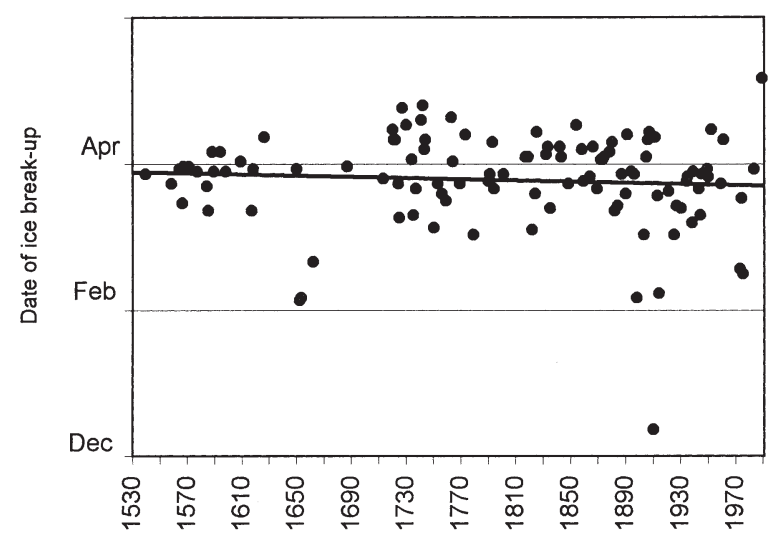

Fig. 3. Time series of date of ice break-up for mild winters with linear trend (1529-1990)

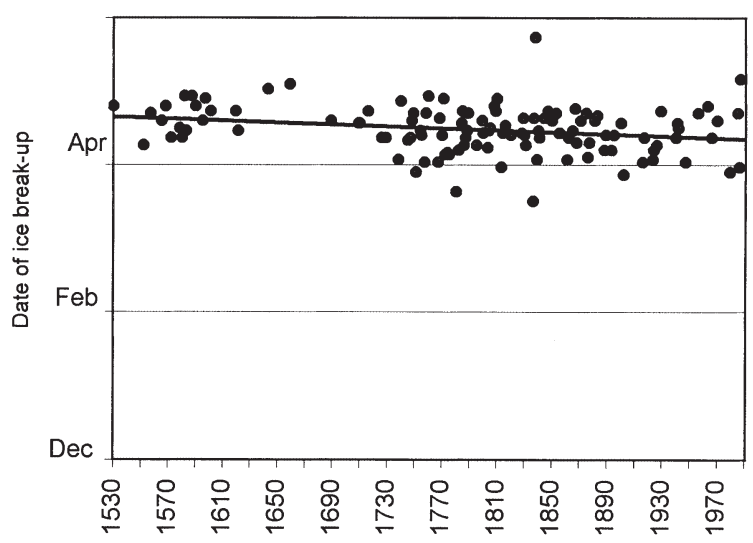

Fig. 4. Time series of date of ice break-up for severe winters with linear trend (1529-1990)

For some years there was disagreement both within the historical data and between reconstructed severity and historical information. An explanation can be presented, for example, for the winter seasons 1915-16 and 1925-26. Those winters were classified as severe for the northern and central Baltic Sea (Betin 1957, Seinä 1996), but for the western Baltic Sea the season was classified as average (quite close to mild). During the winters 1915-16 and 1925-26 the cold anticyclonic air masses covered the northern part of the Baltic Sea and warm air masses from the Atlantic were over the southern part of the sea. In this case a severe winter was observed in the northern part and an average one in the southern part.

Rather interesting was the winter of 1938-39. Winter conditions were average in the southern and mild in the northern parts of the Baltic Sea. This may be due to the influence of cold southeastern air masses over the southern part of the Baltic Sea during March; at the same time warm air masses from the Atlantic were dominant over the northern part of the Baltic Sea. 
Air temperature measurements, reconstructed data from the Climate since AD 1500 database (Bradley 1992) and time series of date of ice break-up at the port of Riga were compared. Correlation coefficients between the seasonal (from December through February) anomalies of air temperature from Stockholm (1755-1980) and Leningrad (1743-1980) and date of ice break-up in the port of Riga were $-0.51(\mathrm{p}<0.01)$ and $-0.5(p<0.01)$, respectively. The correlation coefficient between mean air temperature from December through March in Copenhagen (Betin 1957) and date of ice break-up in the port of Riga was $-0.53(\mathrm{p}<0.01)$ for the period 1767-1860. The date of break-up is observed in April; a better correlation can be obtained by analysis of accumulated air temperature or date of onset of melting air temperatures.

Variation in winter weather in northern Europe is influenced by a fluctuation in the atmospheric mass over the Atlantic Ocean, called the 'North Atlantic oscillation' (Lamb 1977, Rogers 1984, Hurrell 1995). The relation between time series of date of ice breakup at the port of Riga and the NAO winter index was analyzed.

In present study the winter index of the NAO from Climate Analysis Section, Climate and Global Dynamics Division, University Corporation for Atmospheric Research (http://www.cgd.ucar.edu/cas/climind/nao_ winter.html) was used. The winter (December through March) index of the NAO is based on the difference in normalized sea level pressures between Lisbon, Portugal, and Stykkisholmur/Reykjavik, Iceland from 1864 through 1998. The sea level pressure anomalies at each station were normalized by division of each seasonal pressure by the long-term (1864-1983) standard deviation.

Classification of the index data is based on the definition of 3 categories: high, normal and low. A high index $(\mathrm{NAO}>1)$ is associated with strong westerly flow and a low index (NAO <-1)with weak westerlies. A normal index covers $-1<$ NAO $<1$ and indicates a zonal circulation of average strength.

Variations in time series of date of ice break-up at the port of Riga were examined within the context of the atmospheric circulation above the North Atlantic. The correlation coefficient between time series of date of ice break-up and the NAO winter index was -0.57 $(\mathrm{p}<0.01)$. The date of ice break-up of the different type of winter seasons depends on state of the NAO winter index.

\section{CONCLUSION}

The severity of winter seasons has been reconstructed on the basis of historical time series of ice break-up at the port of Riga. There were 111 mild (33\%), 118 average (34\%) and 117 severe (34\%) winters during the period 1529-1990; however, there were some gaps in the data before 1708. Reconstructed severity has been carefully checked with available historical information. An agreement was found for most of the obtained winter seasons.

Trends were analyzed for time series of ice break-up dates, arranged according to the reconstructed severity of winter seasons. No statistically significant trends for average and mild winter seasons were found for the period 1529 to 1990. Only for severe winter seasons was the decreasing trend of about 2.0 d century $^{-1}$ detected with statistical significance at the $99.9 \%$ level. However, periods of early and late break-up were detected using a polynomial fitting curve.

Lengths of periods are not equal; an alternation of maximum and minimum values is clearly seen. There are no fixed cycles, and it is more like a quasi-periodical process. The periods dominated by early break-up include intervals with late date of ice break-up and vice versa.

No trends were found for the severe and average winter seasons and a slightly decreasing trend $(5 \mathrm{~d}$ century $^{-1}$ ) was detected in time series of mild winter seasons during the period 1720-1990. There were no significant changes in ice break-up dates for the severe and average winters from 1720-1990; only for the mild winters the tendency toward early date of ice break-up was observed during the past $270 \mathrm{yr}$.

In a further study, the robust statistical methods and singular spectrum analysis will be applied to elucidate the available historical time series.

Acknowledgements. I would like to thank Dr John C. Moore for helpful comments. I am grateful to anonymous reviewers for constructive criticism. This work received support from the Estonian Ministry of Education and the Väisala Foundation of the Finnish Academy of Science.

\section{LITERATURE CITED}

Betin VV (1957) Ice conditions in different parts of the Baltic Sea and their variations. State Oceanological Institute Publications, Vol 41, Leningrad, p 54-125

Bradley R (1992) Climate since AD 1500 database. IGBR PAGES/World Data Center-Paleoclimatology data contribution series 92-015. NOAA/NGDC Paleoclimatology, Boulder

Buchinsky IE (1957) Climate of Russian plan. Gidrometeoizdat, Leningrad, p 127-129

Camuffo D (1987) Freezing of the Venetian Lagoon since the 9th century A.D. in comparison to the climate of western Europe and England. Clim Change 10:43-66

Catchpole AJW, Hanuta I (1989) Severe summer ice in Hudson Strait and Hudson Bay following major volcanic eruption, 1751-1889 A.D. Clim Change 14:61-79

Girjatowicz J (1990) Atlas zlodzenia wod Polskiego wybrzea 
Battyku, Szczecin. Zaskladu Upowszechniania Postepu, Szczecin, p 11-33

Girjatowicz J, Kozuchowski M (1995) Contemporary changes of Baltic Sea ice. Geogr Pol 65:43-50

Glaser R, Hagedorn H (1991) The climate of Lower Franconia since 1500. Theor Appl Climatol 43:101-104

Henning R (1904) Katalog bemerkenswerter Witterungsereignisse von den ältesten Zeiten bis zum Jahre 1800. Berlin

Hurrell JW (1995) Decadal trends in the North Atlantic oscillation: regional temperatures and precipitation. Science 269:676-679

Jevrejeva S (1999) Some results from the analysis of longterm time series regarding ice conditions along the Estonian coast. Proceeding of Conference POAC '99. Helsinki University of Technology, Espoo, p 354-363

Jevrejeva S (2000) Long-term variability of sea ice and air temperature conditions along the Estonian coast. Geophysica 36:17-30

Jevrejeva S, Leppäranta M (in press) Ice conditions along the Estonian coast: analysis and results. Nordic Hydrol 33(1)

Jurva R (1944) Über die Eisverhältnisse des Baltischen Meers an den Küsten Finnlands. Merentutkimuslaitoksen Jlk./ Havsfordkningsinst Skr. nr. 114, Helsinki

Koslowski G, Glaser R (1995) Reconstruction of the ice winter severity index since 1701 in the Western Baltic. Clim Change 31:79-98

Koslowski G, Glaser R (1999) Variations in reconstructed ice winter severity in the western Baltic from 1501 to 1995, and their implications for the North Atlantic oscillation. Clim Change 41:175-191

Koslowski G, Loewe P (1996) The Western Baltic Sea ice seasons in terms of mass-related severity index 1879-1992. Tellus 46A:66-74

Kraft GV (1887) Description of St. Petersburg ice house in 1740. Moscow

Lamb HH (1977) Climate, present, past and future, Vol 2. Climate history and the future. Methuen \& Co Ltd, London

Pfister C (1992) Monthly temperature and precipitation in Central Europe 1525-1979: quantifying documentary evidence on weather and its effects. In: Bradley RS, Jones PD (eds) Climate since A.D. 1500. Routledge, London

Prüfer G (1942) Die Eisverhältnisse in den deutschen und den
Editorial responsibility: Gerd Esser,

Gießen, Germany ihnen benachbarten Ost und Nordseegebieten. Ann Hydrogr Mar Meteorol LXX (II)

Racz L (1994) The climate of Hungary during the late Maunder minimum (1675-1715). Climatic trends and anomalies in Europe 1675-1716. Gustav Fischer Verlag, Stuttgart

Rannie WF (1983) Break-up and freeze-up of the Red River at Winnipeg, Manitoba, Canada in the 19th century and some climatic implications. Clim Change 5:285-296

Rogers JC (1984) The associations between the North Atlantic oscillation and Southern oscillation in the northern hemisphere. Mon Weather Rev 112:1999-2015

Rudovic LF (1930) Physical-geographical review of the Gulf of Finland, Gulf of Riga, Moodsound. Leningrad State University, Leningrad, p 47-62

Rukachev MA (1886) The freezing and break-up on the Russian Empire. Head Hydrographic Department of the Naval Ministry of Russia, St Petersburg

Seinä A, Palosuo E (1996) The classification of the maximum annual extent of ice cover in the Baltic Sea 1720-1995. Meri 27, Report Series of the Finnish Institute of Marine Research , Helsinki, p 79-91

Shvetc GI (1955) About Dnepr River floods in the last millennium. Hydrological Institute, Ukrainian Academy of Science, Vol 13, Kiev

Speerschneider CIH (1915) Om isforholdene in Danske farvande I aeldre og nyere tid aarene 690-1860. Publikationer fra det Danske Meteorologiske Institut. Meddelelser Nr 2. Kjobenhavn, 141

Stakle P (1936) Die Eisverhältinisse der Ostsee und ihre Erforschung. Sitzungsberichte der finnischen Acadamie der Wissenschaften, Helsinki

Strelow H (1633) Cronica Guthilandorum. Copenhagen

Suhm (1793) Ny Samlinger til den danske Historie. Copenhagen

Sztobryn M (1994) Long term changes in ice conditions at the Polish coast of the Baltic Sea. Proc. IAHR Ice Symposium, Norwegian Institute of Technology, Trondheim, p 345-354

Tarand A (1993) The Tallinn time series of break-up as climate indicator. Tvärmnine, Finland 24-26 August 1993. Department of Geophysics, University of Helsinki. Rep Ser Geophys 27

Thaarup Fr (1776) Bidrag til Kunskab om de danske Provinser. Borholms Amt, Copenhagen

Submitted: March 3, 2000; Accepted: March 5, 2001

Proofs received from author(s): June 27, 2001 